\title{
EEN SCHENKING VAN FORMAAT
}

Wie de tentoonstelling Silk Stories: Taisho kimono 1900-1940 in de Kunsthal in Rotterdam onlangs heeft bezocht, zal bij het betreden van de hoge ruimte onder de indruk geweest zijn van de overweldigende kleurenpracht die zich openbaarde. Meer dan honderd kimono's spreidden zich over de donkere wanden en de blik wist niet zo snel waar te beginnen. Zo verging het mij ook bij de opening van de tentoonstelling en toen Rijksmuseumdirecteur Wim Pijbes vroeg of de verzameling vanuit gezichtspunt van de conservator in het Rijksmuseum op zijn plek zou zijn, luidde het antwoord na even nadenken enigszins tot mijn eigen verrassing, 'ja'. Die bedenktijd was nodig om een behoorlijke omschakeling te maken, want het aandachtsgebied richtte zich vanouds op de kunst van voor 1900, überhaupt niet op textiel en om daar nu zo vanaf te stappen was een hele verandering. Echter, de hoge kwaliteit was evident en dat is tenslotte altijd het leidend principe van het verzamelbeleid geweest, evenals het criterium dat het om kunst gaat die in het land van oorsprong als belangrijk wordt ervaren. Dat geldt zeker voor textiel in Japan, dat vooral in de Edo-periode (1600-1868) een centrale plek innam binnen de kunstnijverheid en waarvan de motieven vooral de versiering op lakwerk en porselein beïnvloedden. Bovendien, hoewel er op het eerste gezicht weinig verband leek te bestaan met de verzameling in het museum - de collectie telt maar één kimono - bleken er bij nader inzien veel aanknopingspunten met andere collectie-onderdelen te zijn. Zo wordt er op het gebied van de prentkunst al een aantal jaar verzameld totaan het midden van de $20^{\mathrm{e}}$ eeuw en op zaal zouden zij een mooie wisselwerking aan kunnen gaan met de kimono's.

Dat geldt eveneens voor de groeiende collectie Japanse fotografie, als ook voor de geschiedenisverzameling, waarbinnen de Tweede Wereldoorlog en dekolonisatie aandachtsgebieden zijn. Een van de opmerkelijke kenmerken van Japanse kimono's uit de vooroorlogse periode is de weerspiegeling op sommige stukken van het opkomende nationalisme, dat niet openlijk werd getoond, maar verborgen ging op mannenonderkimono's. Een wisselopstelling over de Nederlandse aanwezigheid in Azië in de $20^{\mathrm{e}}$ eeuw zou met dit voor veel mensen onverwachte verhaal een interessant accent kunnen krijgen.

\section{Afbeelding 1} Vrouwenkimono met pijnboomtakken, crêpe zijde, h. $168 \mathrm{~cm}$., b. $131 \mathrm{~cm}$., Japan, 19051920, Rijksmuseum AK-RAK-2009-4, Schenking Jan Dees en René van der Star
Hoofdreden voor interesse in de collectie bleef de kwaliteit van de voorwerpen zelf. De vaak gedurfde vlakverdelingen, de adembenemende aandacht voor detail en de verfijnde versieringstechnieken maakten het een voor het museum zeer begerenswaardige groep voorwerpen. Niet in de laatste plaats zouden de kimono's uitstekend passen in het plan voor het Paviljoen voor Aziatische Kunst van het Nieuwe Rijksmuseum, waar een-lange 023 03:08:39pM schilderingenwand is voorzien die ook heel goed voor het tonen van eieen ${ }^{\text {ree access }}$ 

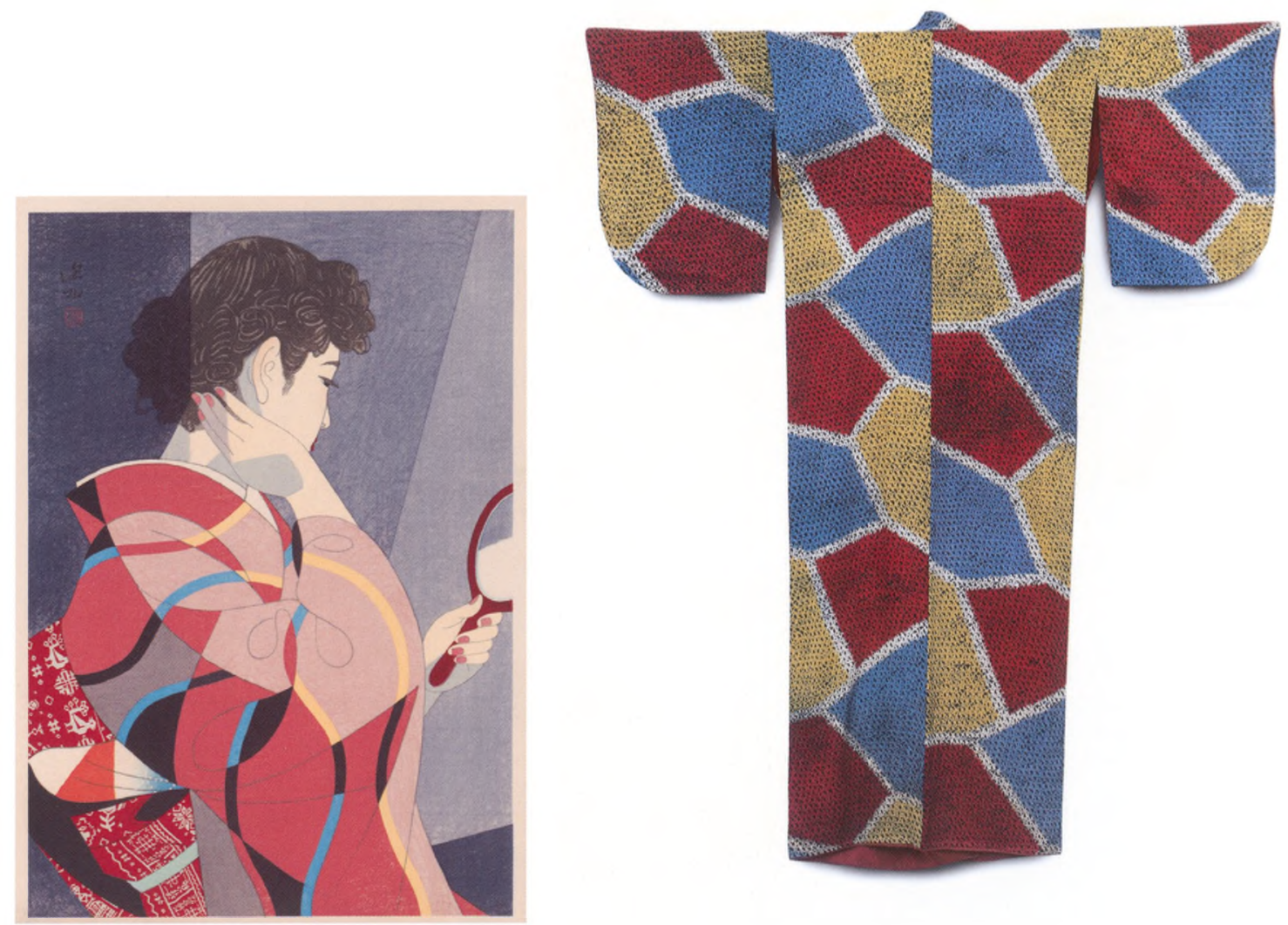

Afbeelding 2 (links) De handspiegel, Ito Shinsui (1898-1972), kleurenhoutsnede, $50 \times$ 36 cm., Japan, 1954, Rijksmuseum RP-P-2002-178

\section{Afbeelding 3}

Vrouwenkimono met geometrische motieven, crêpe zijde, h. $150 \mathrm{~cm}$., b. $126 \mathrm{~cm}$., Japan, 19201940, Rijksmuseum AK-RAK-2009-25, Schenking Jan Dees en René van der Star wisselende selectie kimono's ingezet kan worden, temeer omdat daarmee de aansluiting met de kunstnijverheid en schilderkunst in de nabijgelegen vitrines goed overgebracht kan worden. De verwerving van een grote groep kimono's ineens zou ook betekenen dat er voldoende materiaal was om de lichtgevoelige stukken te kunnen rouleren. Tot slot zou hiermee een begin van een nieuw verzamelterrein worden ontgonnen, want niet alleen zou het de mogelijkheid bieden om de groep aan te vullen met vroegere voorbeelden, er zou ook ineens voldoende houvast zijn om te gaan bouwen aan een substantiëlere kunstnijverheidscollectie van stukken uit de periode 1900-1945.

Kortom, toen in de daaropvolgende tijd duidelijk werd dat de verzamelaars van de tentoongestelde collectie, Jan Dees en René van der Star, geneigd waren om de verzameling in een museum onder te brengen, was het niet moeilijk om daar met groot enthousiasme op te reageren. Wat is er mooier dan zo'n prachtige verzameling te mogen huisvesten, van stukken in uitstekende conditie en bijzonder goed gedocumenteerd in een fraaie catalogus. De resulterende schenking ( 114 kimono's, 12 ceinturen (obi), 2 doeken voor een koto en 9 prenten) onderstreept eens te meer het belang van verzamelaars bij de totstandkoming en ontwikkeling van museale collecties; zij zijn het die vaak gebieden verkennen waar musea nog niet aan toe zijn, daarbij gesteund door de kennis van kundige en betrouwbare handelaren? 910 in 19.78: 39PM kochten Jan en René hun eerste kimono en in de decennia daarna groeide de ${ }^{\text {access }}$ 


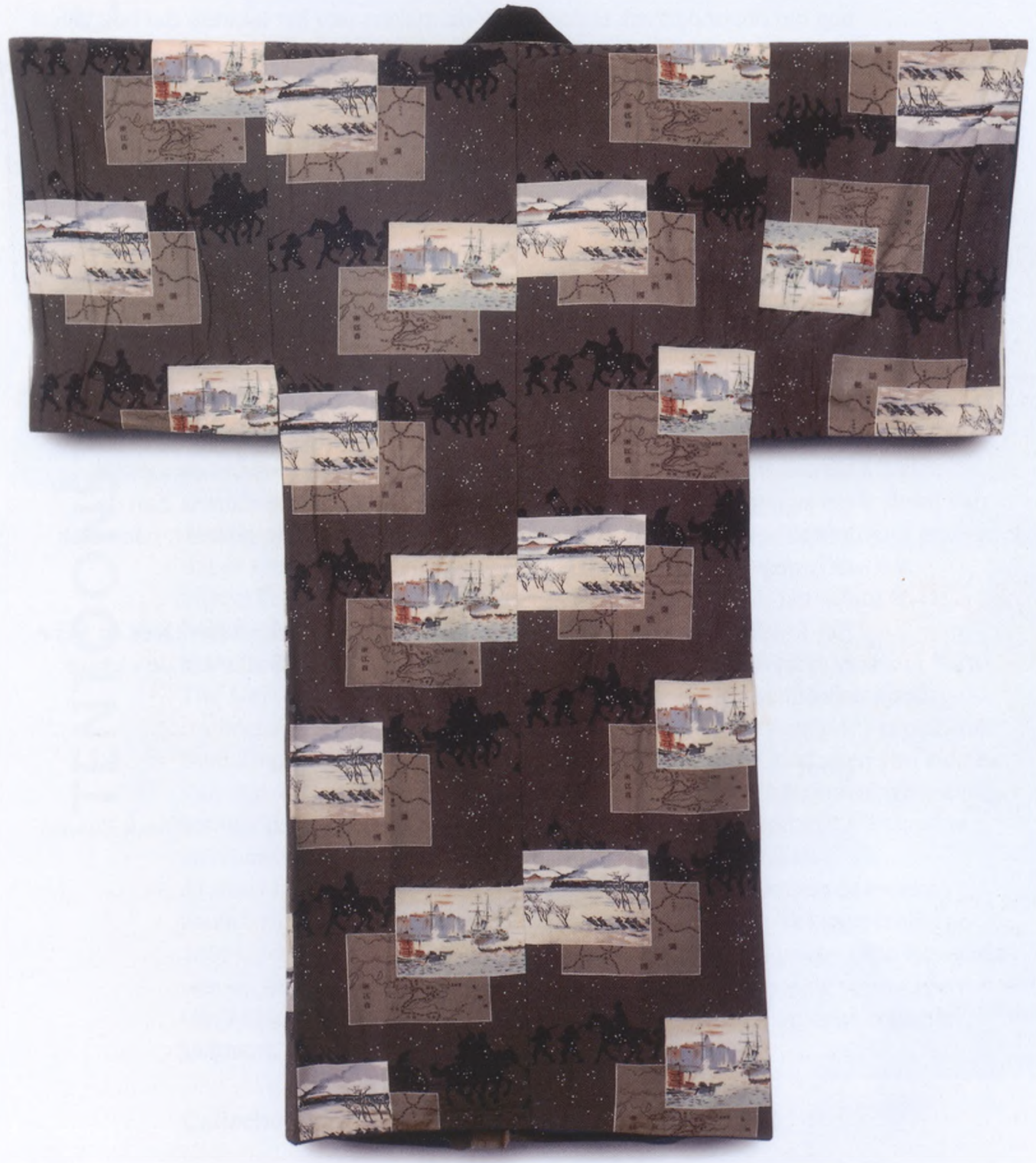

\section{Afbeelding 4}

De Mukden- en

Shanghai-incidenten,

1932. Tegen een achtergrond van silhouetten van soldaten in de sneeuw, zijn scènes van twee schermutselingen in
China afgebeeld.

Mannenonderkimono,

zijde, h. 136 cm., b. 128

cm., Japan, 1932,

Rijksmuseum AK-RAK-

2009-80, Schenking Jan

Dees en René van der

Star 
collectie, waarbij er steevast nauwgezet werd gelet op kwaliteit en conditie. Wat het zo bijzonder maakt is de uitvoerige studie die van het onderwerp werd gemaakt. Jan Dees vond naast zijn drukke baan als medisch specialist nog tijd om onderzoek te doen naar de makers van het lakwerk dat ook zijn aandacht heeft, daarop te promoveren, om vervolgens aan de slag te gaan met textiel, met een gedegen catalogus als resultaat. Stichter van onze Vereniging Westendorp zou instemmend hebben geknikt, van hem is het volgende citaat:

" 'Kunst verzamelen is niet moeilijk' wordt wel eens beweerd. Juist het tegendeel is waar; het komt er maar op aan zich rekenschap te geven, wat onder 'kunst verzamelen' wordt verstaan. Hij die met commercieele doeleinden koopt, of zulks doet, omdat hij meent dat aan zijn stand verplicht te zijn, verdient den eerenaam 'verzamelaar' niet. De ware collectionneur vervult een cultureele roeping, en hij kan dat alleen doen, indien zijn aanleg en begaafdheid hem daartoe in staat stellen. N'est pas collectionneur qui veut! Ieder die geld heeft kan kunst koopen, maar daarom kan hij nog geen verzameling maken. Hij moet de liefde bezitten, gepaard aan de toewijding om zich in de kunst, welke die liefde heeft gewekt, te verdiepen. Aan de innige bevrediging die het opbouwen eener verzameling schenkt, paart zich de drang tot wetenschappelijk onderzoek." 1

Het Rijksmuseum prijst zich gelukkig met verzamelaars als Jan Dees en René van der Star. Hun collectie zal straks een van de parels zijn van de nieuwe opstelling. Was het maar vast zover!

\section{Noot}

1. H.K.W. Westendorp, 'W.F. van Heukelom†', in: Maandblad voor Beeldende Kunsten 14/4 (1937), p. 125. 